\title{
ANALISIS BIAYA SUMBERDAYA DOMESTIK USAHA PENGOLAHAN IKAN TERI NASI KERING
}

\section{DOMESTIC RESOURCE COST ANALYSIS OF BUSINESS OF PROCESSING DRIED TERI FISH}

\author{
Disusun Oleh : \\ Kustiawati Ningsih \\ Dosen Fakultas Pertanian Universitas Islam Madura Pamekasan
}

\begin{abstract}
ABSTRAK
Industri pengolahan ikan di Indonesia hingga saat ini belum memberikan kontribusi nilai tambah yang semestinya dalam pembangunan nasional. Tingkat pengusahaan sumberdaya perikanan di Indonesia yang rata-rata telah mencapai 62 persen, ternyata tidak diimbangi oleh kegiatan peningkatan nilai tambah secara sistematik melalui industri pengolahan hasil perikanan (Departemen Kelautan dan Perikanan, 2010). Oleh karena itu maka untuk memenuhi permintaan produk olahan hasil perikanan, khususnya ikan teri nasi kering (asin) baik dari dalam negeri maupun dari luar negeri diperlukan transaksi yang tidak kecil dan melibatkan banyak tenaga kerja. perkembangan permintaan produk olahan perikanan, termasuk ikan teri nasi kering (asin) cukup prospektif. Namun demikian, usaha pengolahan ikan teri nasi kering (asin) ini memerlukan sumberdaya (modal, lahan, tenaga kerja dan lain-lain) yang tidak sedikit, sedangkan sumberdaya yang tersisa semakin terbatas sehingga harus diusahakan seefisien mungkin.

Berdasarkan kondisi di atas, maka penelitian ini bertujuan untuk menganalisis tingkat pendapatan yang diperoleh dari pengusahaan pengolahan ikan teri nasi kering (asin) dan menganalisis tingkat keunggulan komparatif dan kompetitif pengusahaan pengolahan ikan teri nasi kering (asin) dengan menggunakan analisis Biaya Sumberdaya Domestik. Penelitian dilakukan di PT Kelola Mina Laut (PT KML). Metode analisis yang digunakan adalah analisis Biaya Sumberdaya Domestik (BSD).

Hasil penelitian menunjukkan bahwa secara finansial dan ekonomi, usaha pengolahan ikan teri nasi kering pada orientasi perdagangan promosi ekspor, menghasilkan pendapatan yang menguntungkan. Sedangkan untuk orientasi perdagangan antar daerah menghasilkan pendapatan yang merugikan. Hal ini dicerminkan oleh nilai pendapatan yang negatif. Sementara itu, secara ekonomi usaha pengolahan ikan teri nasi kering di PT KML untuk orientasi PE dan PAD menghasilkan pendapatan yang menguntungkan (nilai pendapatannya positif). Namun demikian, pendapatan ekonomi yang diperoleh oleh usaha pengolahan ikan teri nasi kering, untuk orientasi perdagangan promosi ekspor lebih besar daripada pendapatan finansial. Hal ini menunjukkan bahwa usaha pengolahan ikan teri nasi kering bila dipandang dari segi masyarakat secara keseluruhan (secara ekonomi), lebih menguntungkan daripada apabila dipandang dari segi individu yang terlibat langsung, dalam hal ini pengusaha ikan teri nasi kering, yaitu PT KML. Pendapatan ekonomi yang lebih besar disebabkan adanya perbedaan pada penerimaan dan total biaya yang dikeluarkan.

Usaha pengolahan ikan teri nasi kering di PT KML memiliki keunggulan komparatif dan kompetitif. Keunggulan komparatif dan kompetitif tertinggi diperoleh dari produksi ikan teri nasi kering untuk orientasi perdagangan promosi ekspor. Artinya jika dipandang dari segi masyarakat (secara ekonomi), maka usaha pengolahan ikan teri nasi kering lebih menguntungkan untuk diusahakan daripada dilihat dari segi individunya, yang dalam hal ini adalah pengusaha ikan teri nasi kering.
\end{abstract}

Kata Kunci : Biaya Sumberdaya Domestik, Keunggulan Komparatif, Keunggulan Kompetitif, Ikan Teri Nasi Kerin 


\begin{abstract}
Fish processing industry in Indonesia so far has not contributed added value should be in the national development. Level of exploitation of fishery resources in Indonesia has reached an average of 62 percent, was not offset by an increase in value-added activities in a systematic way through the fish processing industry (Ministry of Maritime Affairs and Fisheries, 2010). Therefore it is to meet the demand for processed fishery products, especially rice dried fish (salty) both from domestic and overseas transactions required small and labor-intensive. Demands development of processed fishery products, including dried anchovy rice (salty) is prospective. However, processing business of anchovy rice (salty) requires resources (capital, land, labor and others) are not small, while the remaining resources are limited so be undertaken as efficiently as possible.

Based on the above conditions, the study aims to analyze the level of income derived from the business of processing dried teri fish (salty) and analyze the level of comparative and competitive advantage of business of processing dried teri fish (salty) using Domestic Resource Cost analysis. The study was conducted at the PT Kelola Mina Laut (PT KML). The method of analysis used is Domestic Resource Cost (BSD) analysis.

The results show that the financial and economic, business of processing dried teri fish for export promotion trade orientation, generating a lucrative income. As for the inter-regional trade orientation income generating harmful. This is reflected by a negative value of income. Meanwhile, in economics, business of processing dried teri fish (salty) in PT KML for PE and PAD orientation generate profitable revenue (revenue positive value). However, the economic income earned by business of processing dried teri fish (salty), for export promotion trade orientation outweigh the financial gains. This suggests that business of processing dried teri fish (salty) when viewed in terms of society as a whole (in the economy), more favorable than when the terms of the individuals involved directly in this businessman of the processing dried teri fish (salty), PT KML. Greater economic returns due to differences in revenue and total cost.

Business of processing fish dried anchovy rice (salty) in PT KML has comparative and competitive advantages. Highest comparative and competitive advantages derived from the production of dried anchovy rice for export promotion trade orientation. This means that if the terms of the (economic), business of processing dried teri fish (salty) is more profitable to cultivate rather than in terms of individuals, which in this case is the businessman anchovy dried rice.
\end{abstract}

Keywords: Domestic Resource Costs, Comparative Advantage, Competitive Advantage, Dried Teri Fish

\section{PENDAHULUAN}

Ikan teri nasi sebagai bagian dari subsektor perikanan, khususnya perikanan laut merupakan salah satu produk perikanan yang mempunyai prospek agribisnis cukup cerah di Indonesia. Industri dalam pengolahan ikan teri nasi menjadi salah satu industri yang berkembang di Indonesia. Industri pengolahan ikan selain mempunyai fungsi sebagai pengintegrasi antar subsistem dalam sistem bisnis perikanan juga mempunyai fungsi penting lainnya seperti (1) mereduksi susut hasil melalui cara penanganan dan pengolahan yang tepat, (2) menyediakan pasokan pangan dan gizi bagi masyarakat melalui diversifikasi produk yang tidak saja merupakan sumber gizi protein, tetapi juga asam lemak tak jenuh berantai panjang khususnya omega-3, vitamin dan mineral, (3) mengembangkan pusat produsen primer, yang dalam jumlah besar masih berada di kawasan timur Indonesia, dengan pusat .konsumen, yang umumnya masih berada di kawasan barat Indonesia dan (4) mendorong berkembangnya industri pangan dan non pangan yang memanfaatkan limbah hasil pengolahan ikan (Departemen Kelautan dan Perikanan, 2010). 
Tabel 1. Perkembangan Volume dan Nilai Ekspor Ikan Teri Nasi Kering (asin), Tahun 2009-2010

\begin{tabular}{|c|c|c|}
\hline Tahun & Volume (Kg) & Nilai (US\$) \\
\hline 2005 & 16206000 & 69183000 \\
\hline 2006 & 20503000 & 87597000 \\
\hline 2007 & 9036000 & 28257000 \\
\hline 2008 & 14323000 & 29375000 \\
\hline 2009 & 8442000 & 22987000 \\
\hline
\end{tabular}

Sumber: BPS diolah oleh Direktorat Jenderal Perikanan, 2010

Dari tabel diatas, dapat dilihat bahwa perkembangan volume dan nilai ekspor ikan teri kering (asin) berfluktuasi. Pada kurun 2005-2006 menunjukkan peningkatan nilai, dimana pada tahun 2005 besarnya nilai ekspor adalah US\$ 69183000 dan pada tahun 2006 terjadi peningkatan sebesar US\$ 87597000. Sedangkan pada tahun 2007 terjadi penurunan volume ekspor menjadi sebesar 9036 ton. Penurunan ini terjadi karena dampak krisis ekonomi yang melanda Indonesia sehingga mengakibatkan terjadinya penurunan volume ekspor. Hal ini disebabkan karena tingginya biaya produksi pengolahan ikan teri nasi kering (asin). Pada tahun 2008 dan 2009 terjadi penurunan volume ekspor 14323 ton menjadi 8442 ton.

Menurut Poernomo et al (2009), industri pengolahan ikan di Indonesia hingga saat ini belum memberikan kontribusi nilai tambah yang semestinya dalam pembangunan nasional. Tingkat pengusahaan sumberdaya perikanan di Indonesia yang rata-rata telah mencapai 62 persen, ternyata tidak diimbangi oleh kegiatan peningkatan nilai tambah secara sistematik melalui industri pengolahan hasil perikanan (Departemen Kelautan dan Perikanan, 2010). Oleh karena itu maka untuk memenuhi permintaan produk olahan hasil perikanan, khususnya ikan teri nasi kering (asin) baik dari dalam negeri maupun dari luar negeri diperlukan transaksi yang tidak kecil dan melibatkan banyak tenaga kerja. Sehingga dalam penelitian ini ingin dilihat seberapa besar pendapatan yang diperoleh dari usaha pengolahan ikan teri nasi kering (asin), baik dilihat dari sisi finansial maupun ekonomi ?.

Selain itu adanya peningkatan permintaan terhadap produk olahan hasil perikanan, terutama ikan teri nasi kering (asin) hingga saat ini belum diimbangi dengan produksi yang ada. Hal ini disebabkan karena makin mahalnya lahan dan tenaga kerja di negara-negara maju. Sehingga kondisi ini memberikan peluang kepada. negara-negara berkembang termasuk Indonesia untuk meningkatkan produksi dan kualitas yang dihasilkannya. Apalagi bisnis pengolahan ikan teri nasi ini mempunyai harapan cerah sebagai mata dagangan antar negara.

Menurut Nurdjana (2010), posisi Indonesia sendiri terhadap pasar produk perikanan dunia, masih tercatat sebagai pengekspor, dimana komoditas perikanan yang antara tahun 2004-2008 mengalami peningkatan 4,3 persen per tahun. Pada tahun 2009 Indonesia telah mengekspor produk perikanan, khususnya ikan teri nasi kering (asin) ke delapan negara di dunia, dengan tujuan utama ekspor adalah Jepang, Cina dan Hongkong. Ekspor Indonesia untuk ketiga negara tersebut cukup besar dan 
kontinyu. Sedangkan ekspor ke negaranegara lainnya seperti Eropa dan Amerika relatif belum berarti, namun masih menandakan adanya peluang ekspor. Volume dan nilai ekspor ikan teri nasi kering (asin) Indonesia pada tahun 2010 menurut negara tujuan ekspor dapat dilihat pada Tabel 2 .

Tabel 2. Volume dan Nilai Ekspor Ikan Teri Nasi Kering (Asin) Indonesia Menurut Negara Tujuan, Tahun 2010

\begin{tabular}{|c|c|c|}
\hline Negara & Volume (Kg) & Nilai (US\$) \\
\hline Jepang & 1478583 & 12421446 \\
\hline Hongkong & 98175 & 138595 \\
\hline Taiwan & 626 & 1929 \\
\hline Cina & 336762 & 878960 \\
\hline Singapura & 52786 & 36050 \\
\hline Filipina & 3423 & 36780 \\
\hline Malaysia & 30200 & 4103 \\
\hline Amerika & 22000 & 91600 \\
\hline Jumlah & $\mathbf{2 0 2 2 5 5 5}$ & $\mathbf{1 3 6 0 9 4 6 3}$ \\
\hline
\end{tabular}

Sumber : BPS diolah Direktorat Jenderal Perikanan, 2010

Dari informasi diatas dapat dilihat bahwa perkembangan permintaan produk olahan perikanan, termasuk ikan teri nasi kering (asin) cukup prospektif. Namun demikian, usaha pengolahan ikan teri nasi kering (asin) ini memerlukan sumberdaya (modal, lahan, tenaga kerja dan lainlain) yang tidak sedikit, sedangkan sumberdaya yang tersisa semakin terbatas sehingga harus diusahakan seefisien mungkin. Oleh karena itu berdasarkan kondisi-kondisi diatas, sampai sejauh mana keunggulan yang dimiliki oleh usaha pengolahan ikan teri nasi kering (asin) tersebut dengan menggunakan analisis Biaya Sumberdaya Domestik?

\section{TUJUAN PENELITIAN}

Berdasarkan perumusan masalah yang telah diuraikan sebelumnya, maka tujuan penelitian ini adalah:

1. Menganalisis tingkat pendapatan yang diperoleh dari pengusahaan pengolahan ikan teri nasi kering (asin).

2. Menganalisis tingkat keunggulan komparatif dan kompetitif pengusahaan pengolahan ikan teri nasi kering (asin) dengan menggunakan analisis Biaya Sumberdaya Domestik.

Hasil penelitian ini diharapkan dapat dijadikan bahan pertimbangan bagi para pengambil keputusan dan pihak-pihak yang terkait lainnya serta sebagai bahan referensi bagi pihak yang memerlukan.

\section{METODE PENELITIAN}

\section{A. Lokasi dan Waktu Penelitian}

Penelitian ini dilakukan di Perusahaan PT Kelola Mina Laut (PT KML) yang terletak di Kecamatan Tlanakan, Kabupaten Pamekasan, Madura, Jawa Timur. Pemilihan lokasi tersebut dilakukan secara sengaja (purposive dengan pertimbangan bahwa PT KML merupakan salah satu produsen ikan teri nasi kering (asin) terbesar di Madura. Ikan teri kering (asin) yang dijual PT KML adalah ikan teri nasi kering yang baik dan berkualitas ekspor. Penelitian dilakukan pada bulan Nopember dan Desember 2011. 


\section{B. Jenis Data}

Data yang digunakan adalah data primer dan data sekunder. Data primer diperoleh dari pengamatan di lapangan dan wawancara dengan manajer produksi dan manajer pengadaan bahan baku di PT KML yang meliputi jumlah input dan biayanya, jumlah output beserta harga jualnya serta data tentang biaya penanganan dan biaya angkut dari komoditas yang diteliti dalam kurun waktu satu tahun yaitu dari bulan Januari 2011 sampai dengan bulan Desember 2011.

Sedangkan data sekunder diperoleh dari PT KML, Departemen Kelautan dan Perikanan, perpustakaan Jurusan Ilmu-ilmu Sosial Ekonomi Pertanian, Pusat Studi Ekonomi dan instansi-instansi terkait lainnya.

\section{Tahapan Analisis Data}

Analisis dilakukan dengan menggunakan analisis Biaya Sumberdaya Domestik (Domestic Resource Cost). Langkah-langkah untuk melakukan analisis BSD adalah :

1. Menetapkan jumlah input yang digunakan dan output yang dihasilkan pada aktivitas ekonomi yang dianalisis.

2. Menentukan penilaian harga bayangan dari input dan output yang diperhitungkan serta nilai tukar uang.

3. Mengalokasikan seluruh biaya input dan output dari aktivitas ekonomi yang dianalisis ke dalam komponen domestik (non tradable) dan asing (tradable).

4. Melakukan analisis pendapatan dari segi finansial dan ekonomi.

5. Melakukan analisis BSD, dengan melihat nilai dan koefisiennya.

\section{Metode Analisis}

\section{Metode Alokasi Komponen Biaya Domestik dan Asing}

Dalam mengalokasikan biaya ke dalam komponen biaya domestik dan asing, terdapat dua pendekatan yaitu: Pendekatan Langsung (Direct Approach) dan Pendekatan Total (Total Approach) (Pearson et al, 1976). Pendekatan langsung sesuai digunakan apabila analisis yang dilakukan adalah keunggulan komparatif dan kompetitif dengan metode BSD. Pendekatan total lebih sesuai digunakan dalam analisa dampak kebijaksanaan atau memperkirakan biaya ekonomi atau bayangan dari struktur yang dilakukan oleh pemerintah. Alokasi komponen biaya domestik dan asing dari penelitian ini menggunakan pendekatan langsung.

Secara ringkas, alokasi biaya produksi dan biaya tataniaga dapat dilihat pada Tabel Lampiran 1 dan Tabel Lampiran 2.

\section{Metode Penentuan Harga Bayangan}

Harga bayangan (harga sosial) adalah harga yang terjadi apabila pasar berada dalam keadaan persaingan sempurna dan dalam kondisi keseimbangan (Gittinger, 1986). Dalam kenyataannya sulit menemukan pasar dalam keadaan persaingan sempurna karena adanya berbagai gangguan akibat kebijaksanaan pemerintah seperti subsidi, pajak dan sebagainya. Harga bayangan dapat dianggap sebagai penyesuaian yang dapat dibuat oleh peneliti proyek terhadap harga pasar dari beberapa faktor produksi atau hasil tersebut, dimana tidak mencerminkan biaya atau nilai bayangan yang sebenarnya (social opportunity cost) dari unsur-unsur hasil produksi tersebut (Clive Gray et al, 1985). 
Untuk lebih lengkapnya harga bayangan output, harga bayangan sarana produksi dan peralatan, harga bayangan tenaga kerja, harga bayangan lahan dan harga bayangan bunga modal dapat dilihat pada Tabel Lampiran 3.

Sedangkan penghitungan harga bayangan nilai tukar mengacu pada pendapat Gittinger (1986), yaitu hubungan antara nilai tukar resmi (OER), premium valuta asing (FX premium), nilai tukar bayangan (SER) dan faktor konversi baku (SCF) adalah sebagai berikut:

OER X $(1+$ FX Premium $)=$ SER

$$
\text { SER }=\frac{\text { OER }}{\text { SCF }}
$$

Penentuan premium valuta asing biasanya dihitung oleh suatu badan pusat karena dalam membandingkan berbagai alternatif dalam kesempatankesempatan investasi cli seluruh negara harus dipakai premium valuta asaing yang sama. Kalau tidak demikian, maka tidak dapat diadakan perbandingan antara alternatif-alternatif tersebut (Oktaviani, 1991). Cara lain untuk menghitung besarnya harga bayangan nilai tukar mata uang asing menurut Rosegrant (1987) dalam Oktaviani (1991) adalah dengan mencari faktor konversi terhadap nilai tukar resmi, sebagai berikut:

$$
\mathrm{SCF}=\frac{\mathrm{M}+\mathrm{X}}{(\mathrm{M}+\mathrm{Tm})+(\mathrm{X}-\mathrm{Xt})}
$$

$$
\begin{aligned}
\text { Keterangan : } \mathrm{M} & =\text { Nilai Impor } \\
\text { Tx } & =\text { Pajak Ekspor } \\
\text { SCF } & =\text { Faktor } \\
\text { Konversi Baku } & \\
\mathrm{X} & =\text { Nilai Ekspor } \\
\text { Tm } & =\text { Pajak Impor }
\end{aligned}
$$

Dalam penelitian ini, angka konversi standar diperoleh dari hasil perhitungan konversi standar tahun 2010, yaitu sebesar 0.997. Besarnya nilai tukar resmi yang digunakan adalah sebesar 10,3S8 rupiah yang diperoleh dari catatan kurs mata uang dolar AS terhadap rupiah di Bank Indonesia sampai dengan bulan Oktober 2010. Dengan demikian maka harga bayangan nilai tukar uang yang digunakan dalam penelitian ini adalah sebesar 10,389 rupiah.

Berdasarkan penjelasan di atas, untuk mengetahui harga bayangan input maupun output usaha pengolahan ikan teri nasi kering, dapat dilihat pada Tabel Lampiran 3.

\section{HASIL PENELITIAN DAN PEMBAHASAN}

\section{A. Analisis Pendapatan Finansial}

Usaha pengolahan ikan teri nasi kering di PT KML dibagi atas dua kegiatan utama, yaitu dalam analisis pendapatan finansial baik untuk orientasi PE maupun PAD, perincian komponen biaya produksi dari kedua proses (proses I dan proses II) tidak disajikan secara terpisah atau digabung. Sedangkan untuk seluruh kegiatan usaha pengolahan ikan teri nasi kering terdapat biaya lain yang harus diperhitungkan yaitu biaya penyusutan peralatan produksi, bunga modal, biaya tenaga kerja tidak langsung, pajak dan biaya tataniaga. Biaya tataniaga dalam penelitian ini didekati dari dua orientasi perdagangan, yaitu pertama orientasi Promosi Ekspor (PE) dan kedua, orientasi Perdagangan Antar Daerah (PAD).

Secara ringkas pendapatan finansial usaha pengolahan ikan teri nasi kering untuk orientasi PE dan PAD di PT KML dapat dilihat pada Tabel 3 di bawah ini. 
Tabel 3. Pendapatan Finansial per kg output Orientasi Promosi Ekspor dan Perdagangan Antar Daerah di PT KML, Tahun 2010/2011 (dalam Rupiah)

\begin{tabular}{|l|l|r|}
\hline Orientasi Perdagangan & \multicolumn{1}{|c|}{ Komponen } & Nilai (Rupiah) \\
\hline \multirow{3}{*}{ Promosi Ekspor } & Penerimaan & $294,569.51$ \\
\cline { 2 - 3 } & Total Biaya & $223,840.47$ \\
\cline { 2 - 3 } & Pendapatan & $70,729.04$ \\
\hline \multirow{3}{*}{ Perdagangan Antar Daerah } & Penerimaan & $100,877.24$ \\
\cline { 2 - 3 } & Total Biaya & $190,055.27$ \\
\cline { 2 - 3 } & Pendapatan & $-89,178.03$ \\
\hline
\end{tabular}

Terlihat dari Tabel 3 bahwa pendapatan finansial ikan teri nasi kering untuk orientasi PE lebih besar dibandingkan pendapatan finansial untuk orientasi PAD, hal ini disebabkan karena harga jual ikan teri nasi kering untuk orientasi PE lebih besar dibandingkan harga jual untuk orientasi PAD, sehingga hal ini akan menyebabkan pendapatan finansial untuk orientasi PE bernilai positif yang menandakan bahwa usaha pengolahan ikan teri nasi kering secara finansial menguntungkan, khususnya untuk orientasi PE. Sedangkan pendapatan finansial untuk orientasi PAD bernilai negatif sehingga secara finansial usaha pengolahan ikan teri nasi kering untuk orientasi PAD kurang menguntungkan.

\section{B. Analisis Pendapatan Ekonomi}

Analisis ekonomi menilai suatu aktivitas berdasarkan atas manfaat yang diperoleh rnasyarakat secara keseluruhan. Dalam analisis finansial, komponen input dan output dinilai dengan menggunakan harga aktual atau harga pasar (market price) yang berlaku di lokasi penelitian. Sedangkan pada analisis ekonomi, komponen input dan output dinilai berdasarkan harga bayangan (shadow price).

Untuk melihat pendapatan ekonomi usaha pengolahan ikan teri nasi kering untuk orientasi promosi ekspor maupun perdagangan antar daerah secara ringkas dapat dilihat pada Tabel 4.

Tabel 4. Pendapatan Ekonomi per kg output untuk Orientasi Promosi Ekspor dan Perdagangan Antar Daerah di PT KML, Tahun 2010/2011 (dalam Rupiah)

\begin{tabular}{|l|l|r|}
\hline Orientasi Perdagangan & \multicolumn{1}{|c|}{ Komponen } & Nilai (Rupiah) \\
\hline \multirow{3}{*}{ Promosi Ekspor } & Penerimaan & $543,383.76$ \\
\cline { 2 - 3 } & Total Biaya & $183,518.59$ \\
\cline { 2 - 3 } & Pendapatan & $359,865.17$ \\
\hline \multirow{3}{*}{ Perdagangan Antar Daerah } & Penerimaan & $295,193.85$ \\
\cline { 2 - 3 } & Total Biaya & $180,045.83$ \\
\cline { 2 - 3 } & Pendapatan & $115,148.02$ \\
\hline
\end{tabular}

Dari Tabel 4 diatas, terlihat bahwa pendapatan ekonomi yang terbesar adalah pendapatan yang berasal dari orientasi promosi ekspor. Usaha pengolahan ikan teri nasi kering dari PT KML ini untuk orientasi promosi ekspor menghasilkan pendapatan ekonomi yang bernilai positif. Hal ini mengindikasikan bahwa secara ekonomi usaha pengolahan ikan teri nasi kering tersebut menguntungkan. 
Sedangkan untuk orientasi perdagangan antar daerah menghasilkan pendapatan ekonomi yang bernilai positif pula, sehingga apabila dibandingkan pendapatan ekonomi untuk orientasi promosi ekspor dengan perdagangan antar daerah, maka dapat dilihat bahwa pendapatan ekonomi yang diperoleh untuk promosi ekspor lebih besar dibandingkan pendapatan ekonomi untuk orientasi perdagangan antar daerah. Hal ini menunjukkan bahwa usaha pengolahan ikan teri nasi kering bila dipandang dari segi masyarakat secara keseluruhan (secara ekonomi), lebih menguntungkan daripada apabila dipandang dari segi individu yang terlibat langsung, dalam hal ini adalah pengusaha ikan teri nasi kering, yaitu PT KML. Pendapatan ekonomi yang lebih besar ini disebabkan adanya perbedaan pada penerimaan dan total biaya $y$ ang dikeluarkan.

Penerimaan dipengaruhi oleh harga output, yaitu ikan teri nasi kering. Dalarn analisis finansial, harga output dinilai berdasarkan harga aktual yang berlaku di lokasi penelitian. harga untuk ikan teri nasi kering dibedakan berdasarkan mutu atau grade dan orientasi perdagangan. Sedangkan pada analisis ekonomi, harga bayangan output per kilogram untuk orientasi promosi ekspor lebih tinggi 26.07 persen, sedangkan harga bayangan output untuk orientasi perdagangan antar daerah lebih tinggi 34.26 persen dari harga aktualnya. Lebih tingginya harga bayangan output yang digunakan dalam analisis ekonomi ini mengakibatkan peningkatan penerimaan yang diperoleh. Apalagi untuk orientasi perdagangan PE perbedaan harga bayangan dengan harga aktualnya mencapai 20 persen. Hal ini disebabkan karena pada harga bayangan untuk orientasi PE digunakan harga f.o.b (free on board) yang dihitung berdasarkan nilai ekspornya di pelabuhan ekspor dengan menggunakan nilai dolar.

Dengan demikian berdasarkan analisis pendapatan finansial dan ekonomi yang telah dilakukan diatas, walaupun besarnya nilai yang diperoleh kedua pendapatan tersebut berbeda tetapi keduanya bernilai positif, terutama pendapatan untuk orientasi PE, sehingga dapat ditarik kesimpulan bahwa usaha pengolahan ikan teri nasi kering untuk orientasi promosi ekspor di PT KML menguntungkan.

Sedangkan untuk orientasi PAD, pada pendapatan finansial kurang menguntungkan (bernilai negatif), sementara itu untuk pendapatan ekonomi bernilai positif, dimana hal ini menunjukkan bahwa usaha pengolahan ikan teri nasi kering di PT KML untuk orientasi PAD menguntungkan, secara ekonomi. Disarnping itu dapat juga ditarik kesimpulan pendapatan yang diperoleh melalui pendekatan ekonomi memberikan hasil yang lebih tinggi dibandingkan dengan pendapatan yang diperoleh melalui pendekatan finansial.

\section{Analisis Keunggulan Kompetitif}

Analisis keunggulan kompetitif berbeda dengan analisis keunggulan komparatif. Pada analisis keunggulan kompetitif, analisis BSD dihitung berdasarkan harga finansiai atau harga aktual yang terjadi di lokasi penelitian dan nilai tukar uang yang berlaku.

$$
\text { Suatu negara atau daerah }
$$

dikatakan memiliki keunggulan kompetitif apabila nilai KBSD* atau koefisien BSD* yang dihitung berdasarkan harga aktual, lebih kecil dari satu sehingga dapat dikatakan bahwa usaha untuk menghasilkan komoditi tersebut secara finansial efisien dalam menghemat sumberdaya domestik yang digunakan. 
Hasil dari analisis keunggulan kompetitif usaha pengolahan ikan teri nasi kering untuk orientasi perdagangan promosi ekspor maupun perdagangan antar daerah yang tercerminkan dalam nilai BSD* dan KBSD* dapat dilihat dan disarikan pada Tabel 5 dibawah ini.

Tabel 5. Nilai BSD* dan KBSD* Usaha Pengolahan Ikan Teri Nasi Kering untuk Orientasi Promosi Ekspor dan Perdagangan Antar Daerah di PT KML, Tahun 2010/2011

\begin{tabular}{|c|c|c|c|}
\hline \multicolumn{2}{|c|}{ Promosi Ekspor } & \multicolumn{2}{c|}{ Perdagangan Antar Daerah } \\
\hline BSD* & KBSD* & BSD* & KBSD* \\
\hline Rp. 7,866.97/US\$ & 0.757 & Rp. 19,528.14/US\$ & 1.885 \\
\hline
\end{tabular}

Dari Tabel 5 tersebut dapat dilihat bahwa orientasi perdagangan promosi kspor dalam usaha pengolahan ikan teri nasi kering di PT KML mempunyai nilai BSD* yang lebih kecil dari nilai tukar uang resmi yang berlaku yaitu sebesar 0,358.00 rupiah per dolar AS. Namun, untuk orientasi perdagangan antar daerah, nilai BSD* lebih besar dari nilai tukar uang resmi yang berlaku. Dari nilai BSD* ang lebih kecil dari nilai tukar uang resmi yang berlaku, maka untuk orientasi PE akan menghasilkan KBSD* lebih kecil dari satu yaitu sebesar 0.757. Sedangkan untuk orientasi PAD, nilai KBSD* lebih besar dari satu, yaitu sebesar 1.885, sehingga dari nilai KBSD* untuk orientasi PAD ini dapat dikatakan bahwa usaha pengolahan ikan teri nasi kering tidak mempunyai keunggulan kompetitif yang dapat menyebabkan usaha ini tidak dapat bersaing di pasar internasional. Namun, hal ini terjadi sebaliknya untuk orientasi PE, dimana nilai KBSD* sebesar 0.757 menunjukkan bahwa usaha pengolahan ikan teri nasi kering di PT KML mempunyai keunggulan kompetitif dan dapat bersaing di pasar internasional dengan asumsi adanya sistem pemasaran dan intervensi dari pemerintah.

Apabila perusahaan dihadapkan pada pilihan produksi, maka produksi ikan teri nasi kering untuk orientasi PE lebih efisien secara finansial dibanding produksi ikan teri nasi kering untuk orientasi PAD. Hal ini ditunjukkan dari nilai KBSD* yang lebih kecil dari satu, seperti yang terlihat pada Tabel 5, mengartikan bahwa ikan teri nasi kering lebih memiliki keunggulan kompetitif, khususnya untuk orientasi PE. Dan hal ini juga menandakan bahwa untuk memperoleh manfaat finansial tertinggi sebaiknya produksi ikan teri nasi kering diarahkan untuk orientasi PE.

\section{Analisis Keunggulan Komparatif}

Analisis Sumberdaya Domestik (BSD) merupakan salah satu alat yang digunakan untuk mengukur apakah suatu aktivitas tertentu memiliki keunggulan komparatif atau tidak. Menurut Kadariah et al (1978), analisis Biaya Sumberdaya Domestik (BSD) dapat digunakan untuk mengukur besarnya sumberdaya nasional untuk memperoleh atau menghemat satu unit devisa. Dalam analisis keunggulan komparatif, analisis BSD dihitung berdasarkan harga bayangan dan nilai tukar bayangan.

Sedangkan Pearson et al (1976) dalam Wahyudi mengemukakan bahwa suatu komoditi mempunyai keunggulan komparatif apabila nilai koefisien BSD (KBSD) yang dihitung berdasar nilai sosialnya lebih kecil dari satu, yang 
berarti bahwa biaya sosial dari pengusahaan komoditi tersebut lebih kecil daripada penerimaannya, sehingga dapat dikatakan bahwa secara ekonomi komoditi tersebut menguntungkan apabila diusahakan. Sebaliknya, apabila nilai KBSD lebih besar dari satu, maka aktivitas tersebut secara ekonomi tidak layak diusahakan karena tidak mempunyai keunggulan komparatif. Apabila terdapat dua atau lebih aktivitas yang dianalisis, maka akbi-vitas yang mempunyai nilai KBSD lebih kecil dari satu (terendah dengan nilai positif) merupakan aktivitas yang layak secara ekonomi.

Pada Tabel 6, dapat dilihat hasil perhitungan nilai BSD dan KBSD usaha pengolahan ikan teri nasi kering untuk orientasi promosi ekspor (PE) dan perdagangan antar daerah (PAD) di lokasi penelitian, yaitu di PT KML.

Tabel 6. Nilai BSD dan KBSD Usaha Pengolahan Ikan Teri Nasi Kering untuk Orientasi Promosi Ekspor dan Perdagangan Antar Daerah di PT KML, Tahun 2010/2011

\begin{tabular}{|c|c|c|c|}
\hline \multicolumn{2}{|c|}{ Promosi Ekspor } & \multicolumn{2}{c|}{ Perdagangan Antar Daerah } \\
\hline BSD & KBSD & BSD & KBSD \\
\hline Rp. 3,505.30/US\$ & 0.337 & Rp. 6,333.36/US\$ & 0.609 \\
\hline
\end{tabular}

Dari Tabel 6, dapat diamati bahwa KBSD untuk orientasi promosi ekspor (PE) bernilai kurang dari satu yaitu sebesar 0.337. Sedangkan nilai KBSD untuk orientasi Perdagangan Antar Daerah (PAD) bernilai lebih kecil dari satu yaitu 0.609. Nilai BSD untuk orientasi PE sebesar Rp. 3,505.30/US\$ dan nilai BSD untuk orientasi PAD sebesar Rp. 6,333.36/US\$, dimana nilai BSD baik untuk orientasi PE maupun PAD bernilai lebih kecil dari harga bayangan nilai tukar uang yang bernilai 10,389.00 rupiah per dolar.

Untuk orientasi perdagangan PE, nilai BSD yang lebih kecil dari harga bayangan nilai tukar uang menggambarkan bahwa sumberdaya domestik yang digunakan dalam usaha pengolahan ikan teri nasi kering di PT KML efisien secara ekonomi untuk menghemat satu unit devisa. Atau dengan kata lain, untuk menghasilkan satu satuan unit devisa, hanya diperlukan harga bayangan nilai tukar uang sebesar 10,389.00 rupiah per dolar. Demikian pula halnya pada orientasi PAD, nilai BSD rnenunjukkan lebih kecil dari harga bayangan nilai tukar uang, dimana hal ini menandakan bahwa pemanfaatan sumberdaya domestik dalam usaha pengolahan ikan teri nasi kering di PT KML efisien secara ekonomi untuk menghemat satu unit devisa.

Nilai KBSD untuk orientasi perdagangan $\mathrm{PE}$ yang bernilai 0.337 menggambarkan bahwa usaha pengolahan ikan teri nasi kering di PT KML sangat layak secara ekonomi. Namun, nilai KBSD untuk orientasi PAD sebesar 0.609, menunjukkan bahwa usaha pengolahan ikan teri nasi kering di PT KML juga layak secara ekonomi. Dari nilai KBSD yang bernilai kurang dari satu, yaitu KBSD untuk orientasi PE, yang bernilai sebesar 0.337 mempunyai arti bahwa untuk menghasilkan satu satuan devisa yang dinilai dengan harga bayangan nilai tukar uang hanya diperlukan pengorbanan sebesar 0.337. Sedangkan untuk orientasi PAD yang mempunyai nilai KBSD sebesar 0.609 mengartikan bahwa untuk menghasilkan satu satuan devisa yang dinilai dengan harga 
bayangan nilai tukar uang diperlukan pengorbanan yang sebesar 0.609, sehingga dengan nilai KBSD yang lebih kecil dari satu ini, maka produksi ikan teri nasi kering di PT KML mempunyai keunggulan komparatif dan dapat dikatakan efisien secara ekonomi dalam pemanfaatan sumberdaya domestik. Sedangkan pada orientasi PE, nilai KBSD yang lebih kecil dari satu menunjukkan bahwa produksi ikan teri nasi kering di PT KML mempunyai keunggulan komparatif atau efisien secara ekonomi dalam penggunaan sumberdaya domestik. Dengan kata lain, secara ekonomi usaha pengolahan ikan teri nasi kering di PT KML layak diusahakan untuk diekspor maupun untuk diperdagangkan ke daerah lain.

Semakin rendahnya nilai KBSD akan menunjukkan semakin layaknya suatu usaha. Oleh karena itu, berdasarkan nilai KBSD, usaha pengolahan ikan teri nasi kering di PT KML layak dilakukan untuk orientasi perdagangan promosi ekspor dan orien^lasi perdagangan antar daerah.

Dari perbandingan hasil KBSD antara kedua orientasi perdagangan pada Tabel 6 tersebut, menunjukkan bahwa keunggulan komparatif yang dimiliki oleh produksi ikan teri nasi kering untuk orientasi promosi ekspor lebih tinggi dibanding produksi dengan tujuan perdagangan antar daerah. Hal ini disebabkan oleh tingginya harga jual ikan teri nasi kering untuk ekspor, yaitu sebesar US \$ 7.75 atau 80,274.50 rupiah per kilogramnya, sedangkan untuk orientasi PAD harga jualnya lebih rendah, hanya sebesar 9,000.00 rupiah per kilogramnya.

Dari hasil BSD dan KBSD tersebut, dapat disimpulkan bahwa usaha pengolahan ikan teri nasi kering di PT KML mempunyai keunggulan komparatif, apabila produksi ikan teri nasi kering ditujukan untuk orientasi promosi ekspor dan perdagangan antar daerah, sehingga produksi dapat dikembangkan di PT KML dan menguntungkan secara ekonomi untuk terus dilanjutkan dalam rangka menghasilkan devisa negara melalui kegiatan ekspornya.

Jika Tabel 5 dan Tabel 6 tersebut dibandingkan, maka dapat dilihat bahwa nilai KBSD pada analisis keunggulan komparatif mempunyai nilai lebih kecil daripada nilai KBSD* hasil analisis keunggulan kompetitif, khususnya untuk orientasi perdagangan promosi ekspor. Dengan kata lain, usaha pengolahan ikan teri nasi kering lebih mempunyai keunggulan komparatif. Artinya, jika dipandang dari segi masyarakat (secara ekonomi), maka usaha pengolahan ikan teri nasi kering tersebut menguntungkan untuk diusahakan daripada dilihat dari segi individunya, yang dalam hal ini adalah pengusaha ikan teri nasi kering.

Tetapi apabila tujuan dari usaha pengolahan ikan teri nasi kering tidak disertai dengan usaha untuk meningkatkan pendapatan yang diperoleh perusahaan, tentunya hal tersebut tidak ada artinya. Hal ini disebabkan karena pengusaha adalah individu yang terlibat secara langsung dalam proses produksi, sehingga keuntungan yang diperoleh merupakan hal penting yang harus diperhatikan sehingga keuntungan yang dihasilkan dapat lebih optimal untuk menjaga kesinambungan hidup perusahaan, kesejahteraan bagi seluruh karyawan serta keuntungan bagi pemegang saham. Faktor penyebab utama adalah pada analisis keunggulan komparatif harga output dinilai berdasarkan harga bayangan yang lebih tinggi dari harga aktualnya. Oleh karena itu, pada analisis keunggulan komparatif nilai penerimaan menjadi lebih tinggi dibandingkan nilai penerimaan pada 
analisis keunggulan kompetitif, terutama untuk orientasi perdagangan promosi ekspor. Nilai penerimaan yang lebih tinggi ini akan mengakibatkan nilai KBSD rendah pada analisis keunggulan komparatif.

Dari nilai KBSD yang lebih kecil dari satu, mencerminkan bahwa tanpa adanya campur tangan dari pemerintah, usaha pengolahan ikan teri nasi kering sudah mempunyai keunggulan komparatif, terutama untuk orientasi perdagangan promosi ekspor. Oleh karena itu, usaha pengolahan ikan teri nasi kering tersebut sangat efisien dalam penggunaaan sumberdaya domestik sehingga pemenuhan kebutuhan domestik akan lebih menguntungkan dengan meningkatkan produksi, sehingga dengan keadaan seperti ini, pemerintah juga harus tetap mempertahankannya untuk mencapai keadaan yang semakin mantap dari keunggulan komparatif tersebut.

Bila dilihat dari keunggulan kompetitif, ternyata usaha pengolahan ikan teri nasi kering untuk orientasi Promosi Ekpor dan Perdagangan Antar Daerah masih kurang kompetitif, sehingga hal ini mengindikasikan bahwa pada saat ini masih ada harnbatan-hambatan yang bersifat disinsentif seperti perpajakan atau pungutan-pungutan liar serta prosedur pengaturan administrasi yang bersifat menghambat kegiatan produksi. Namun, berdasarkan pengamatan di lokasi penelitian, penyebabnya adalah karena masih tingginya biaya produksi terutama biaya pembelian ikan teri nasi basah dan masih kurang insentifnya harga output yang terjadi.

Dalam perdagangan ikan teri nasi kering, baik yang ditujukan untuk orientasi perdagangan promosi ekspor maupun orientasi perdagangan antar daerah, penilaian terhadap komoditas tersebut sangat ditentukan oleh mutu atau kualitas dari ikan teri nasi kering tersebut. Hal ini didukung dengan adanya pemisahan mutu atau grade dari ikan teri nasi kering tersebut, dimana ikan teri nasi kering yang gradenya paling tinggi, harganya lebih mahal dibanding ikan teri nasi kering yang gradenya lebih rendah. Karena ikan teri nasi kering yang dihasilkan oleh PT KML ini 100 persen diekspor ke Jepang, maka mutu produk menjadi hal terpenting,. dimana Jepang merupakan negara yang sangat ketat dalam hal mutu. Selain faktor mutu produk, dalam penentuan harga suatu komoditi juga dipengaruhi oleh faktor-faktor lain, yaitu negara pesaing, tingkat permintaan dan harga produk substitusi.

Berdasarkan hal tersebut upaya yang perlu dilakukan pemerintah untuk memantapkan keunggulan kompetitif diantaranya melalui peningkatan peranan Departemen Kelautan dan Perikanan (DKP) dalam melakukan pembinaan melalui Petugas Penyuluh Lapangan (PPL) terhadap petani nelayan mengenai pentingnya kualitas atau mutu bahan baku yang mereka sediakan untuk perusahaan pengolah hasil perikanan, seperti PT KML. Pembinaan oleh PPL juga harus diberikan kepada perusahaan pengolah hasil perikanan, khususnya mengenai pentingnya keterkaitan anlara perusahaan pengolah hasil perikanan dengan subsistem-subsistem lainnya. Sebagai upaya agar agro/marine based dapat berdaya saing kuat dan dapat bertahan lama, maka perusahaan pengolah hasil perikanan harus melakukan keterkaitan baik ke depan (forward linkage) maupun ke belakang (backward linkage). Keterkaitan antara perusahaan pengolah hasil perikanan dengan subsistem lainnya, meliputi: keterkaitan perusahaan pengolah hasil perikanan dengan sumberdaya alam dan pemasarannya, perusahaan pengolah 
hasil perikanan dengan industri pengolahan lain yaitu industri hulu/dasar, industri hilir dan industri kecil, perusahaan pengolah hasil perikanan dengan industri pendukungnya antara lain industri mesin, industri agrokimia, industri pengemasan dan lain-lain serta keterkaitan perusahaan pengolah hasil perikanan dengan sektor ekonomi dan sektor-sektor lainnya, antara lain sektor perhubungan, jasa dan perbankan.

Selain itu dukungan dari kelembagaan keuangan seperti Perbankan sangat diharapkan. Misalnya, pemberian kredit dengan bunga rendah melalui prosedur dan persyaratan yang lebih mudah dan terjangkau, serta sistem pengembalian yang sesuai dengan pola usaha yang ada di bidang perikanan. Disamping itu, adanya Forum Kontak Tani Nelayan Andalan (KTNA) yang mulai dirintis saat ini dapat lebih dikembangkan oleh pemerintah sebagai wahana pengendalian dan pengelolaan produk hasil perikanan.

Sedangkan upaya yang dapat dilakukan oleh pihak perusahaan untuk memantapkan keunggulan kompetitif diantaranya dengan menekan biaya produksi melalui efisiensi dan pengalokasian sumberdaya yang optimal, misalnya dengan mengurangi biaya pembelian ikan teri nasi basah (bahan baku) sesuai dengan jumlah output yang direncanakan oleh perusahaan, sehingga output yang dihasilkan tidak berlebihan karena hal tersebut akan menurunkan rendemen produk yang telah ditetapkan oleh perusahaan, yaitu rata-rata 15 persen. Penurunan rendemen ini dapat menurunkan mutu produk yang dihasilkan dan otomatis akan menurunkan harga output tersebut. Untuk mengurangi atau meminimalkan penurunan mutu produk tersebut, pengendalian secara preventif dapat lebih diperhatikan atau diutamakan. Tindakan preventif yang dapat dilakukan antara lain menetapkan standar mutu bahan baku melalui penetapan kriteria faktor mutu bahan baku seperi warna ikan, jenis ikan, banyaknya campuran, kesegaran ikan serta bau ikan. Selain itu pencegahan penurunan mutu produk dapat dilakukan dengan pengujian mutu bahan baku, misalnya melalui penggunaan analisa organoleptik secara sederhana yang menggunakan indera penglihatan dan indera penciuman. Pengawasan mutu selama proses produksi juga menjadi hal yang penting dan harus diperhatikan oleh perusahaan.

Dari hasil analisis keunggulan komparatif dan kompetitif seperti yang telah dijelaskan diatas, secara umum menunjukkan kecenderungankecenderungan hasil yang sama. Kecenderungan tersebut adalah: pertama, usaha pengolahan ikan teri nasi kering di PT KML, lebih menguntungkan secara ekonomi jika diproduksi untuk orientasi promosi ekspor, karena harga jualnya yang lebih tinggi daripada orientasi perdagangan antar daerah; kedua, usaha pengolahan ikan teri nasi kering di PT KML kurang menguntungkan secara finansial jika diproduksi untuk orientasi perdagangan antar daerah, tetapi lebih menguntungkan jika diproduksi untuk orientasi promosi ekspor.

Dari seluruh penjelasan diatas, dapat disimpulkan bahwa usaha pengolahan ikan teri nasi kering untuk orientasi promosi ekspor dan perdagangan antar daerah di PT KML menguntungkan untuk terus dikembangkan, dimana usaha tersebut memiliki keunggulan komparatif. Sedangkan untuk orientasi perdagangan promosi ekspor dan perdagangan antar daerah, khususnya dari hasil analisis 
keunggulan kompetitif, usaha tersebut k:urang memiliki keunggulan kompetitif.

\section{KESIMPULAN DAN SARAN}

\section{A. Kesimpulan}

Usaha pengolahan ikan teri nasi kering di PT KML untuk orientasi perdagangan promisi ekspor (PE) maupun perdagangan antar daerah (PAD), meliputi dua kegiatan utama yang saling melengkapi. Pertama, proses I yaitu kegiatan yang menangani dan mengolah ikan teri nasi basah (bahan baku) menjadi ikan teri nasi kering. Proses I ini dimulai dari kegiatan penimbangan bahan baku, pencucian, pentirisan, perebusan sampai kegiatan penjemuran. Kedua, proses II yaitu kegiatan penanganan produk akhir (finish goods) yang terdiri dari kegiatan sortasi, sizing, packing dan penyimpanan produk akhir ke dalam cold storage.

Secara finansial dan ekonomi, usaha pengolahan ikan teri nasi kering pada orientasi perdagangan promosi ekspor, menghasilkan pendapatan yang menguntungkan. Sedangkan untuk orientasi perdagangan antar daerah menghasilkan pendapatan yang merugikan. Hal ini dicerminkan oleh nilai pendapatan yang negatif. Sementara itu, secara ekonomi usaha pengolahan ikan teri nasi kering di PT KML untuk orientasi PE dan PAD menghasilkan pendapatan yang menguntungkan (nilai pendapatannya positif). Namun demikian, pendapatan ekonomi yang diperoleh oleh usaha pengolahan ikan teri nasi kering, untuk orientasi perdagangan promosi ekspor lebih besar daripada pendapatan finansial. Hal ini menunjukkan bahwa usaha pengolahan ikan teri nasi kering bila dipandang dari segi masyarakat secara keseluruhan (secara ekonomi), lebih menguntungkan daripada apabila dipandang dari segi individu yang terlibat langsung, dalam hal ini pengusaha ikan teri nasi kering, yaitu PT KML. Pendapatan ekonomi yang lebih besar disebabkan adanya perbedaan pada penerimaan dan total biaya yang dikeluarkan.

Usaha pengolahan ikan teri nasi kering di PT KML memiliki keunggulan komparatif dan kompetitif. Keunggulan komparatif dan kompetitif tertinggi diperoleh dari produksi ikan teri nasi kering untuk orientasi perdagangan promosi ekspor.

Namun, dari hasil analisis keunggulan komparatif dan kompetitif yang diperoleh, menunjukkan bahwa usaha pengolahan ikan teri nasi kering di PT KML lebih mempunyai keunggulan komparatif terutama untuk orientasi perdagangan promosi ekspor dan perdagangan antar daerah. Artinya jika dipandang dari segi masyarakat (secara ekonomi), maka usaha pengolahan ikan teri nasi kering lebih menguntungkan untuk diusahakan daripada dilihat dari segi individunya, yang dalam hal ini adalah pengusaha ikan teri nasi kering.

\section{B. Saran}

Dilihat dari hasil analisis keunggulan komparatif dan kompetitif dengan nilai KBSD dan KBSD*nya, maka sebaiknya usaha pengolahan ikan teri nasi kering di PT KML diarahkan pada produksi ikan teri nasi kering dengan orientasi perdagangan promosi ekspor.

$\begin{array}{ccc}\begin{array}{c}\text { Adanya } \\ \text { Pengelolaan }\end{array} & \text { Forum } & \text { Koordinasi } \\ \text { dan } & \text { Pemanfaatan }\end{array}$
Sumberdaya Ikan (FKPPS) yang mulai dirintis saat ini dapat dikembangkan oleh pemerintah sebagai wahana pengendalian dan pengelolaan produk hasil perikanan, sehingga masyarakat, khususnya pengusaha produk olahan 
hasil perikanan, dapat membantu pemerintah untuk lebih mernantapkan keunggulan kompetitif. Selain itu, lembaga keuangan seperti perbankan berperan penting juga dalam pemberian kredit dengan bunga ndah melalui prosedur dan persyaratan yang lebih terjangkau, serta sistem ngembalian yang sesuai dengan pola usaha yang ada di bidang perikanan, sehingga ini bisa menjadi insentif bagi pengusaha untuk meningkatkan daya saing produknya terutama untuk produk yang dijual ke daerah lain sehingga keunggulan kompetitif menjadi lebih mantap.

$$
\text { Sedangkan dari pihak }
$$

perusahaan sendiri, untuk memantapkan keungguulan kompetitif dapat dilakukan dengan menekan biaya produksi melalui efisiensi dan pengalokasian sumberdaya yang optimal, misalnya dengan menekan biaya pembelian bahan teri nasi basah (bahan baku), dimana jumlah bahan baku yang dibeli sesuai dengan jumlah produksi yang direncanakan.

Selain itu, upaya lain yang dapat dilakukan perusahaan adalah melalui tindakan preventif terhadap tindakan yang dapat menurunkan mutu produk, yaitu dengan melakukan pengawasan terhadap mutu, mulai dari bahan baku yang gunakan, proses produksi sampai menjadi produk akhir, sehingga dengan adanya tindakan preventif ini mutu produk dapat memiliki daya saing yang lebih tinggi dan harga output menjadi lebih baik (lebih memberikan insentif) dan hal ini dapat memantapkan keunggulan kompetitif.

\section{BIBLIOGRAFI}

Badan Pusat Statistik. Oktober 2010. Statistik Perdagangan Luar Negeri Indonesia.
Badan Pusat Statistik. Oktober 2010. Indikator Ekonomi. Buletin Statistik Bulanan.

Direktorat Jenderal Perikanan Budidaya. 2001. Statistik Ekspor Hasil Perikanan Tahun 2010. Departemen Kelautan dan Perikanan. Jakarta.

Gray, Clive et al. 1985. Pengantar Evaluasi Proyek. PT Gramedia. Jakarta. Gittinger, 1986. Analisa Ekonomi Proyek-proyek Pertanian. Edisi Kedua. UI Press. Jakarta.

Hutomo, M et al. 1987. Sumberdaya Ikan Teri di Indonesia. Pusat Penelitian dan Pengembangan Oseanologi-LIPI. Jakarta.

Hardjamulia, Atmadja et al. 2001. Analisis Kebijaksanaan Pembangunan Perikanan. Pusat Riset Perikanan Budidaya, Badan Riset Kelautan dan Perikanan, Departemen Kelautan dan Perikanan. Jakarta.

Hartati, Ucu. 2001. Analisis Keunggulan Komparatif dan Kompetitif Pengusahaan Minyak Akar Wangi, Desa Sukakarya, Kecamatan Semarang dan Desa Dano, Kecamatan Leles, Kabupaten Garut. Skripsi. Jurusan Ilmuilmu Sosial Ekonomi Pertanian. Fakultas Pertanian. Institut Pertanian Bogor. Bogor.

Nurdjana, Made L. 2010. Mewujudkan Perikanan Sebagai Prime Mover Ekonomi Kerakyatan. Volume I, No.2, Desember. Hal 38-40. Jakarta.

Noegroho, Anang. 2010. Sektor Kelautan dan Perikanan Membutuhkan Pedoman Investasi. Bisnis Indonesia, 29 Januari. Jakarta. 
Oktaviani, Rina. 1991. Efisiensi Ekonomi dan Dampak Kebijakan Insentif Pertanian pada Produksi Komoditas Pangan di Indonesia. Thesis. Pasca Sarjana Institut Pertanian Bogor. Bogor.

Putri, Indrijuli Magsari. 2001. Analisis Keunggulan Komparatif dan Kompetitif Usahatani Mentimun Jepang dengan Analisis Biaya Sumberdaya Domestik, Studi Kasus pada Petani Mitra PT X di Empat Kabupaten, Jawa Tengah. Skripsi. Jurusan Ilmu-ilmu Sosial Ekonomi Pertanian. Fakultas Pertanian. Institut Pertanian Bogor. Bogor.

Pranindya, Raden Mas Agung. 2001. Keunggulan Komparatif dan Kompetitif serta Dampak Kebijaksanaan Pemerintah pada Produksi Teh Hitam (CTC), Suatu Kasus pada PT Perkebunan Nusantara VIII, Perkebunan Gunung Mas, Kecamatan Cisarua, Kabupaten Bogor, Jawa Barat. Skripsi. Jurusan Ilmu-ilmu Sosial Ekonomi Pertanian. Fakultas Pertanian. Institut Pertanian Bogor. Bogor.

Soewito et al. 2000. Sejarah Perikanan Indonesia. Yasamita. Jakarta.

Suryana, Achrnad. 1980. Keuntungan Komparatif dalam Produksi Ubi Kayu dan Jagung di Jawa Timur dan Lampung dengan Analisa Penghematan Biaya Sumberdaya Domestik. Thesis. Pascasarjana Institut Pertanian Bogor. Bogor.

Suryana, Rita Nurmalina et al. 1996. Keunggulan Komparatif; Keunggulan Kompetitif dan
Dampak Kebijaksanaan Pemerintah dalam Produksi Kapas di Indonesia. Penelitian Hibah Bersaing Tahun Anggaran 1995/1996.

Salvatore, Dominick. 1997. Ekonomi Internasional. Erlangga. Jakarta.

Widya, Novianti. 2001. Analisis Keunggulan Komparatif dan Kompetitif Produksi Cabai Merah dengan Analisis Biaya Sumberdaya Domestik Studi Kasus PT Qurnia Sumber Alam Raya, Kabupaten Sukabumi, Jawa Barat. Skripsi. Jurusan Ilmu-ilmu Sosial Ekonomi Pertanian. Fakultas Pertanian. Institut Pertanian Bogor. Bogor.

Wahyudi, Yunita. 2001. Analisis Keunggulan Komparatif dan Kompetitif Produksi Krisan Potong dengan Menggunakan Analisis Biaya Sumberdaya Domestik Studi Kasus PT X Desa Karang Luwuk, Kecamatan Sukaresmi Cipanas, Jawa Barat. Skripsi. Jurusan Ilmu-ilmu Sosial Ekonomi Pertanian. Fakultas Pertanian. Institut Pertanian Bogor. Bogor.

Yanti, Junita Sesi. 1999. Kajian Pengembangan Usaha Pengolahan Ikan Teri Asin, Studi Kasus pada Industri Kecil di Kelurahan Karan Aur, Kecamatan Pariaman Tengah, Kabupaten Padang Pariaman, Propinsi Sumatera Barat. Skripsi. Program Studi Sosial Ekonomi Perikanan. Fakultas Peikanan dan Ilmu Kelautan. Institut Pertanian Bogor. Bogor. 
Tabel Lampiran 1. Pengalokasian Komponen Biaya Berdasarkan Komponen Domestik dan Asing

\begin{tabular}{|c|c|c|c|}
\hline URAIAN & DOMESTIK & ASING & PAJAK \\
\hline A. INPUT & & & \\
\hline 1. Ikan Teri Nasi Basah & 100 & & \\
\hline 2. Garam & 100 & & \\
\hline 3. Minyak Tanah & 100 & & \\
\hline 4. Solar & 86.70 & 12.79 & 2.09 \\
\hline 5. Tenaga Kerja & 100 & & \\
\hline 6. Penyusutan & & & \\
\hline a. Bangunan sortasi & 100 & & \\
\hline b. Bangunan sizing dan packing & 100 & & \\
\hline c. Cold storage & 100 & & \\
\hline d. Bak pencucian & 100 & & \\
\hline e. Bak perebusan & 100 & & \\
\hline f. $\quad$ Peralatan produksi & 72.51 & 23.98 & 3.5 \\
\hline 7. Bunga modal & 100 & & \\
\hline 8. Sewa lahan & 100 & & \\
\hline 9. Listrik & 95.62 & 3.65 & 0.73 \\
\hline B. TATANIAGA & & & \\
\hline 1. Pengangkutan & 95.72 & 3.23 & 1.05 \\
\hline 2. $\quad$ Penanganan & 98.50 & 0.72 & 0.78 \\
\hline
\end{tabular}

Sumber : Tabel Input-Output, Tahun 2010

Tabel Lampiran 2. Biaya Tataniaga Usaha Pengolahan Ikan Teri Nasi Kering PT KML, Tahun 2010/2011

\begin{tabular}{|c|c|c|c|c|c|}
\hline \multirow{2}{*}{$\begin{array}{c}\text { Orientasi } \\
\text { Perdagangan }\end{array}$} & \multirow[t]{2}{*}{ Rute } & \multicolumn{3}{|c|}{ Biaya Tataniaga (Rp/kg) } & \multirow[t]{2}{*}{ Tujuan } \\
\hline & & Pengangkutan & Penanganan & Total & \\
\hline $\mathrm{PE}$ & $\begin{array}{l}\text { Produsen- } \\
\text { pelabuhan } \\
\text { ekspor }\end{array}$ & 45.86 & 5243.48 & 5289.34 & $\begin{array}{l}\text { Pelabuhan } \\
\text { Tanjung Perak } \\
\text { (Surabaya) }\end{array}$ \\
\hline PAD & $\begin{array}{l}\text { Produsen- } \\
\text { distributor }\end{array}$ & 410.00 & 4451.90 & 4861.96 & Bogor \\
\hline
\end{tabular}

Keterangan :

1. Biaya pengangkutan

2. Biaya penanganan

a. Promosi Ekspor (PE) terdiri dari : biaya angkut dari lokasi produksi ke pelabuhan ekspor (Tanjung Perak, Surabaya)

b. Perdagangan Antar Daerah (PAD) terdiri dari : biaya angkut dari lokasi produksi ke distributor (Bogor).

a. Promosi Ekspor (PE) terdiri dari : biaya pengemasan, biaya karantina, biaya dokumen dan biaya sewa gudang di pelabuhan ekspor.

b. Perdagangan Antar Daerah (PAD) terdiri dari : biaya pengemasan (biaya sortir, pengepakan dan bongkar muat) 
Tabel Lampiran 3. Harga Aktual dan Harga Bayangan Per Satuan Input-Output yang digunakan dalam Usaha Pengolahan Ikan Teri Nasi Kering

\begin{tabular}{|c|c|c|c|}
\hline Uraian & Satuan & Harga Aktual (Rp) & $\begin{array}{c}\text { Harga Bayangan } \\
\text { (Rp) }\end{array}$ \\
\hline \multicolumn{4}{|l|}{ A. OUTPUT } \\
\hline \multicolumn{4}{|l|}{ 1. Promosi Ekspor } \\
\hline a. $\quad$ Grade A & $\mathrm{Rp} / \mathrm{kg}$ & $80,274.50$ & $307,913.04$ \\
\hline b. $\quad$ Grade B & $\mathrm{Rp} / \mathrm{kg}$ & $72,506.00$ & $277,603.00$ \\
\hline c. Grade C & $\mathrm{Rp} / \mathrm{kg}$ & $67,327.00$ & $256,612.69$ \\
\hline \multicolumn{4}{|l|}{ 2. $\quad$ Perdagangan Antar Daerah } \\
\hline a. $\quad$ Grade $\mathrm{A}$ & $\mathrm{Rp} / \mathrm{kg}$ & $9,000.00$ & $308,340.42$ \\
\hline b. Grade B & $\mathrm{Rp} / \mathrm{kg}$ & $8,500.00$ & $278,030.51$ \\
\hline c. Grade C & $\mathrm{Rp} / \mathrm{kg}$ & $8,000.00$ & $257,040.07$ \\
\hline \multicolumn{4}{|l|}{ B. INPUT } \\
\hline 1. Ikan Teri Nasi Basah & $\mathrm{Rp} / \mathrm{kg}$ & $5,000.00$ & $5,000.00$ \\
\hline 2. $\quad$ Garam & $\mathrm{Rp} / \mathrm{kg}$ & 350.00 & 350.00 \\
\hline 3. Minyak Tanah & Rp/liter & 900.00 & 900.00 \\
\hline 4. $\mathrm{Es}$ & Rp/balok & $3,500.00$ & $3,500.00$ \\
\hline 5. Solar & Rp/liter & $1,150.00$ & $1,150.00$ \\
\hline 6. $\quad$ Tenaga Kerja & $\mathrm{Rp} / \mathrm{HOK}$ & $7,200.00$ & $7,200.00$ \\
\hline $\begin{array}{l}\text { 7. Penyusutan } \\
\text { a. Bangunan sortasi }\end{array}$ & Rp/tahun & $825,000.00$ & $825,000.00$ \\
\hline $\begin{array}{ll}\text { b. } & \begin{array}{l}\text { Bangunan sizing dan } \\
\text { packing }\end{array} \\
\end{array}$ & Rp/tahun & $1,650,000.00$ & $1,650,000.00$ \\
\hline c. Cold storage & Rp/tahun & $15,000.000 .00$ & $15,000.000 .00$ \\
\hline d. Bak pencucian & Rp/tahun & $140,000.00$ & $140,000.00$ \\
\hline e. Bak perebusan & Rp/tahun & $300,000.00$ & $300,000.00$ \\
\hline 8. Listrik & Rp/tahun & $5,300,000 ; 00$ & $5,300,000 ; 00$ \\
\hline 9. Sewa Lahan & Rp/ha/th & $3,000,000.00$ & $3,000,000.00$ \\
\hline 10. Bunga Modal & $\% /$ tahun & 13,40 & - \\
\hline C. NILAI TUKAR & Rp/US\$ & $10,358.00$ & $10,389.00$ \\
\hline
\end{tabular}

